\title{
Catenococcus thiocyclus gen. nov. sp. nov. - a new facultatively anaerobic bacterium from a near-shore sulphidic hydrothermal area
}

\author{
DIMITRY YU. SOROKIN \\ Institute of Microbiology, Prospect 60-let Octyabrya 7a, 117811 Moscow, Russia
}

(Received 27 May 1992; revised 21 July 1992; accepted 27 July 1992)

\begin{abstract}
A new Gram-negative facultatively anaerobic eubacterium isolated from a near-shore sulphidic hydrothermal area is described. It differs from known genera of Gram-negative cocci, and is thus proposed to be a representative of a new genus. This isolate, Catenococcus thiocyclus, is able to oxidize thiosulphate to tetrathionate during batch growth in the presence of organic carbon and energy sources. That energy is gained from thiosulphate oxidation is indicated by an increase in the growth yield compared with similar cultures from which the thiosulphate had been omitted. Thiosulphate-cytochrome $c$ oxidoreductase and endogenous cytochrome $c_{553}$ were shown to be involved in thiosulphate oxidation in $C$. thiocyclus.
\end{abstract}

\section{Introduction}

The ability of heterotrophic bacteria to oxidize reduced sulphur compounds has been found to be more widespread than previously believed (Kuenen, 1989; Kelly \& Harrison, 1989; Sorokin, $1991 a$; Robertson \& Kuenen, 1992). Most of the strains thus far studied in detail produce sulphate (Kelly \& Harrison, 1989; Robertson $e t$ al., 1989; Kuenen et al., 1992), but a large number, especially members of the genus Pseudomonas, oxidize thiosulphate to tetrathionate (Tuttle \& Jannasch, 1972; Sorokin, 1992). This phenomenon has also been observed in some facultatively anaerobic, fermentative bacteria (Mason \& Kelly, 1988).

During investigations of microbial physiology at nearshore hydrothermal areas in Matupy Harbour (New Britain Island, Papua New Guinea), a number of thiosulphate-oxidizing bacteria were isolated (Sorokin, $1991 b$ ). Most of the strains that produced tetrathionate from thiosulphate morphologically resembled members of the genera Pseudomonas or Vibrio, but others did not. This paper presents a description of a new species in a newly defined genus.

\section{Methods}

Isolation and culture. Strain TG 5-3 was isolated from a water sample from a near-shore sulphidic hydrothermal area at a depth of $0.5 \mathrm{~m}$ in Matupy Harbour of New Britain Island, Papua New Guinea. It appeared as a dense upper layer in sulphide gradient tube enrichments (Jørgensen, 1989) supplemented with acetate, and was isolated on solid mineral medium with acetate and thiosulphate after aerobic incubation at $28^{\circ} \mathrm{C}$.
The mineral medium contained the following $\left(\mathrm{g}^{-1}\right)$ : $\mathrm{NH}_{4} \mathrm{Cl}, 0.5$; $\mathrm{MgSO}_{4} .7 \mathrm{H}_{2} \mathrm{O}, 0.3 ; \mathrm{CaCl}_{2} .2 \mathrm{H}_{2} \mathrm{O}, 0.1 ; \mathrm{KH}_{2} \mathrm{PO}_{4}$ and $\mathrm{K}_{2} \mathrm{HPO}_{4}$, between 2 and 10 depending on the required $\mathrm{pH}$ and buffering capacity; yeast extract, 0.05; $\mathrm{NaCl}, 20$; trace elements (Pfennig \& Lippert, 1966), $1 \mathrm{ml}$. Unless otherwise stated, $10 \mathrm{~mm}$-acetate was provided as the carbon source. For solid media, $2 \%(\mathrm{w} / \mathrm{v})$ bacto-agar (Merck) was added. Organic substrates were as shown in the text. When different nitrogen sources were to be tested during growth on acetate, the $\mathrm{NH}_{4}^{+}$was omitted and $\mathrm{KNO}_{3}\left(0.5 \mathrm{~g}^{-1}\right)$, urea $\left(0.5 \mathrm{~g} \mathrm{l}^{-1}\right)$ or $\mathrm{NaNO}_{2}\left(0.1 \mathrm{~g} \mathrm{t}^{-1}\right)$ was provided instead.

The ability to ferment sugars was assayed in Hungate tubes which had been flushed for $10 \mathrm{~min}$ with $\mathrm{O}_{2}$-free argon. Chemolithoautotrophic growth was tested aerobically in mineral medium with $20 \mathrm{~mm}$ thiosulphate. Anaerobiosis for the fermentation and sulphate- and sulphur-reduction experiments was confirmed by the failure of a control culture of strain TG 5-3 to grow in medium containing acetate as the substrate, as acetate can only support growth of this strain in the presence of oxygen. The $\mathrm{pH}$ optimum for growth was determined in strongly buffered media of different initial $\mathrm{pH}$ values. During growth, samples were taken for $\mathrm{pH}$ and optical density determinations, and the $\mathrm{pH}$ was then adjusted with sterile $\mathrm{KH}_{2} \mathrm{PO}_{4}$ solution. The growth rate, length of the lag phase and onset of lysis were used in the analysis. API 20B, API 20NE and API20E identification microplates (MontalieuVercileu, France) were used for the rapid determination of common taxonomic features. The results of these tests were analysed using the taxonomic database of the Netherlands Culture Collection (NCC).

Analytical techniques. Thiosulphate and tetrathionate were measured by iodometric titration (Goehring et al., 1949) and by cyanolysis (Sörbo, 1957). Sulphate was determined turbidimetrically (Cypionka \& Pfennig, 1986). Protein was measured by the Lowry method with BSA (Sigma) as standard. Products of glucose fermentation by strain TG 5-3 were analysed by HPLC as follows: Animex HPX-87C column, Waters UV-absorbance detector, Spectra-Physics SP4270 integrator, temperature $20^{\circ} \mathrm{C}$, carrier solvent $0.002 \mathrm{M}-\mathrm{H}_{2} \mathrm{SO}_{4}$, with a flow rate of $0.6 \mathrm{ml} \mathrm{min}^{-1}$.

Electron microscopy. Samples for electron microscopy were prepared by the methods described by Dawes (1971). Material for ultra-thin 
sections was fixed with glutaraldehyde and post-fixed with $1 \%(\mathrm{w} / \mathrm{v})$ $\mathrm{OsO}_{4}$. The ultra-thin sections were stained with uranyl acetate for $1 \mathrm{~h}$, and then with lead citrate for $40 \mathrm{~min}$. Intact cells were negatively stained with ammonium molybdate. A Philips EM 201C transmission electron microscope was used.

Miscellaneous. Thiosulphate-oxidizing activity in cell extracts was determined by measuring rates of ferricyanide (Mason \& Kelly, 1988) or oxidized cytochrome $c_{550}$ (Tuttle et al., 1983) reduction in the presence of thiosulphate. All measurements were done in $0.1 \mathrm{M}$ potassium phosphate buffer, $\mathrm{pH} 6.7$, with $2 \%(\mathrm{w} / \mathrm{v}) \mathrm{NaCl}$. Cytochrome reduction by thiosulphate was monitored using a Pye-Unicam 1800 spectrophotometer. Cytochrome spectra of whole cells after reduction by dithionite were made at room temperature using an Aminco DW-2 UV/Vis spectrophotometer attached to an Apple Macintosh computer for data processing. DNA extraction and purification, and determination of DNA base composition, were done as described by Marmur (1961).

\section{Results}

\section{Morphology and growth}

Strain TG 5-3 was a Gram-negative, non-motile coccus (Fig. 1 $a$ ) forming chains (Fig. $1 b$ ) which were usually surrounded by a slime layer (Fig. 1c,d). The size of the cells varied between 0.6 and $1.2 \mu \mathrm{m}$. In rapidly growing cultures on solid medium containing yeast extract and peptone, rod-like cells (which eventually divided to form cocci) were sometimes observed at the edges of colonies. Rod-like forms were rarely observed in liquid media. Division was within a single plane (Fig. $1 e, f$ ). The $\mathrm{mol} \%$ $\mathrm{G}+\mathrm{C}\left(T_{\mathrm{m}}\right)$ was $49 \cdot 8 \pm 0 \cdot 5$.

Colonies on solid media with acetate were large $(\leq 10 \mathrm{~mm})$, round, white, with an opaque centre and translucent edge. After prolonged incubation ( 2 weeks) the colour of the colony became yellowish. Growth in static liquid cultures occurred as slime layers on the surface, which formed a sediment with time.

Growth was $\mathrm{NaCl}$ dependent and occurred over a range between 0.5 and $8 \%(\mathrm{w} / \mathrm{v}) \mathrm{NaCl}$, with the optimum concentration between 2.5 and $3.5 \%$. Growth took place over the pH range 5.6-7.8, with the optimum at 6.7-6.9. If $\mathrm{Mg}^{2+}$ or $\mathrm{Ca}^{2+}$ levels were low, or if the $\mathrm{pH}$ was allowed to increase above $7 \cdot 5$, spheroplast formation and lysis occurred. Lysis was observed with organic acids (acetate, pyruvate, succinate, lactate) and thiosulphate (because of the hydroxyl ions generated during tetrathionate formation), but not with glucose (presumably because of the acids formed during fermentation). The temperature range for growth was $10-35^{\circ} \mathrm{C}$, with the optimum at $25-28{ }^{\circ} \mathrm{C}$.

\section{Physiology}

Strain TG 5-3 was both catalase and oxidase positive. Growth on sugars was more rapid than on other organic compounds. Aerobic growth on the following sugars, and on starch, resulted in acid formation: D-glucose, Dmaltose, $\alpha, \alpha$-trehalose, sucrose, fructose. Aerobic growth on cellobiose and L-arabinose did not result in acid formation. All of these sugars, except L-arabinose, supported anaerobic growth. The main products of glucose fermentation were formate and acetate, with succinate and lactate appearing transiently. Strain TG 53 also grew aerobically on acetate, succinate, malate, fumarate, pyruvate, gluconate, citrate, lactate, malonate, 2-oxoglutarate, propionate, butyrate, ethanol, propanol, glycerol, mannitol, L-aspartate, glutamate, proline, DLcysteine and histidine. It did not grow on galactose, raffinose, L-rhamnose, D-lactose, melibiose, D-xylose, glyoxylate, glycolate, benzoate, caproate, formate, methanol, butanol, sorbitol, dulcitol, meso-inositol or 2propanol. The complex vitamin mixture described by Pfennig \& Lippert (1966) did not stimulate growth of TG 5-3 on $10 \mathrm{~mm}$-acetate; therefore individual vitamins were not tested. Tween-80 was hydrolysed. Poly $\beta$ hydroxybutyrate and polyphosphate sometimes accumulated in cells grown on acetate and glucose, respectively.

Ammonium, nitrate and nitrite served as nitrogen sources. Metabolism was either aerobic or fermentative; denitrification did not occur with nitrate $\left(1 \mathrm{~g} \mathrm{l}^{-1}\right)$ or nitrite $\left(0 \cdot 1 \mathrm{~g} \mathrm{l}^{-1}\right)$. However, strain TG 5-3 could reduce nitrate to nitrite. Spectra of dithionite-reduced cells revealed the characteristic peaks of cytochromes $c$ and $b$.

From the results of the API 20 systems, it appeared that strain TG 5-3 expressed $\beta$-galactosidase, tryptophan deamidase and aminopeptidase, but did not express urease, arginine dehydrogenase, $\beta$-glucosidase or ornithine decarboxylase. It did not produce $\mathrm{H}_{2} \mathrm{~S}$ from thiosulphate, make acetoin, hydrolyse gelatin or grow on McConkey agar.

Growth of strain TG 5-3 was inhibited by the following antibiotics ( $\mu \mathrm{g}$ per sensitivity disc): chloramphenicol, 10 ; streptomycin, 25 ; tetracycline, 50 ; erythromycin, 10; ampicillin, 2; kanamycin, 30; colistin sulphate, 10; nitrofurantoin, 200; sulfafurazole, $500 ; 3$ IU of penicillin G. It was not inhibited by $5 \mu \mathrm{g}$ cloxacillin or $25 \mu \mathrm{g}$ cephaloridine.

Strain TG 5-3 oxidized thiosulphate to tetrathionate in batch cultures supplied with an organic substrate, but could not grow autotrophically on thiosulphate. The thiosulphate-oxidizing system appeared to be constitutive, but the level of activity in the culture increased for several hours after exposure to thiosulphate. Thiosulphate oxidation and tetrathionate formation paralleled growth (Fig. 2). A maximum thiosulphate oxidation rate of $1.17 \mu \mathrm{mol} \mathrm{min}^{-1}$ (mg protein ${ }^{-1}$ ) by whole cells was observed. Both the growth rate and biomass yield of cultures growing on acetate increased when the medium was supplemented with thiosulphate (Fig. $3 a-c$ ), and the 

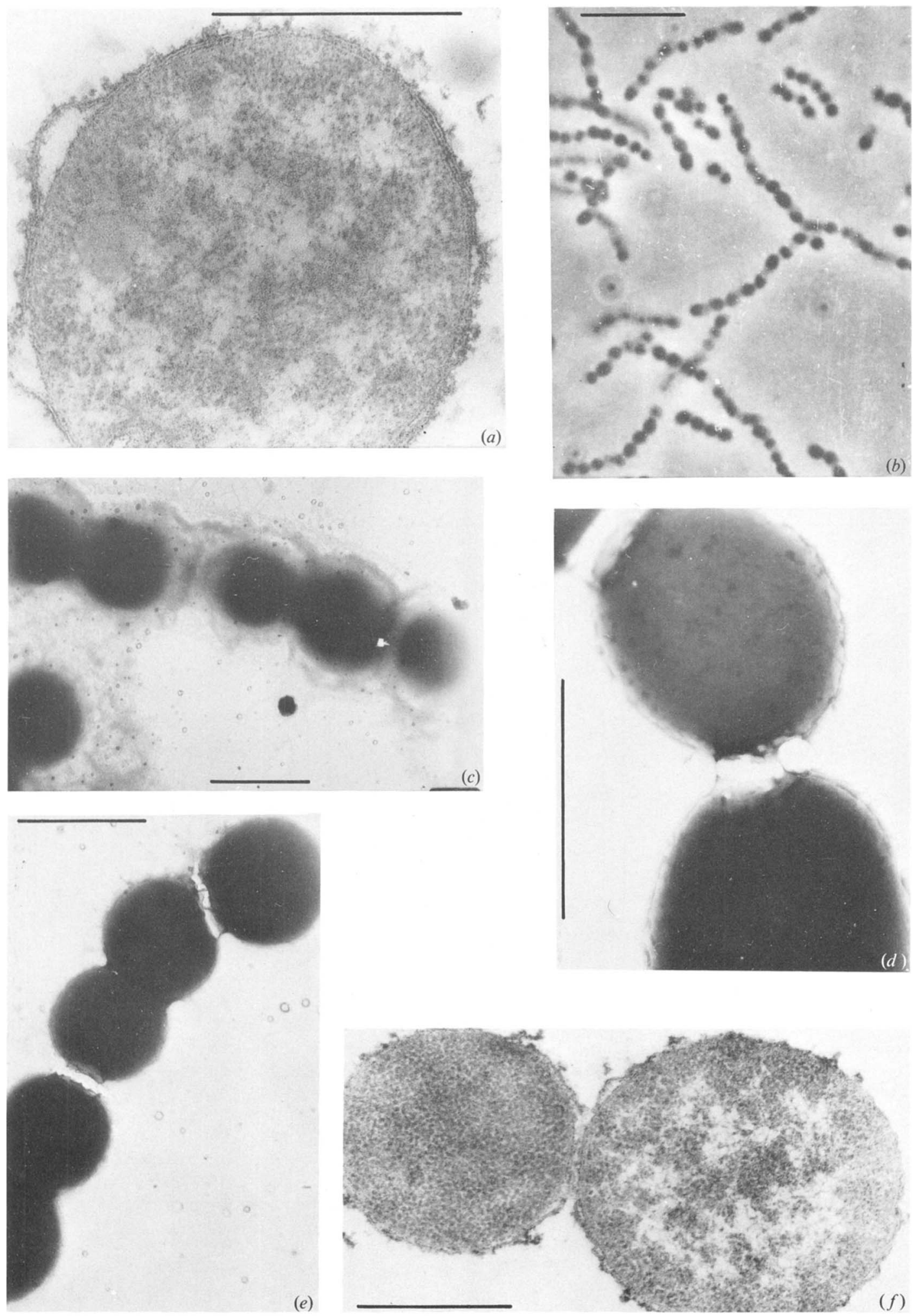

Fig. 1. Morphology of strain TG 5-3. (a,f) Electron micrographs of ultrathin sections; bars, $0.5 \mu \mathrm{m}$; (b) Phase-contrast micrograph of a culture grown in liquid medium with acetate; bar, $10 \mu \mathrm{m} .(c, d, e)$ Electron micrographs of whole cells stained with ammonium molybdate; bars, $1 \mu \mathrm{m}$. 


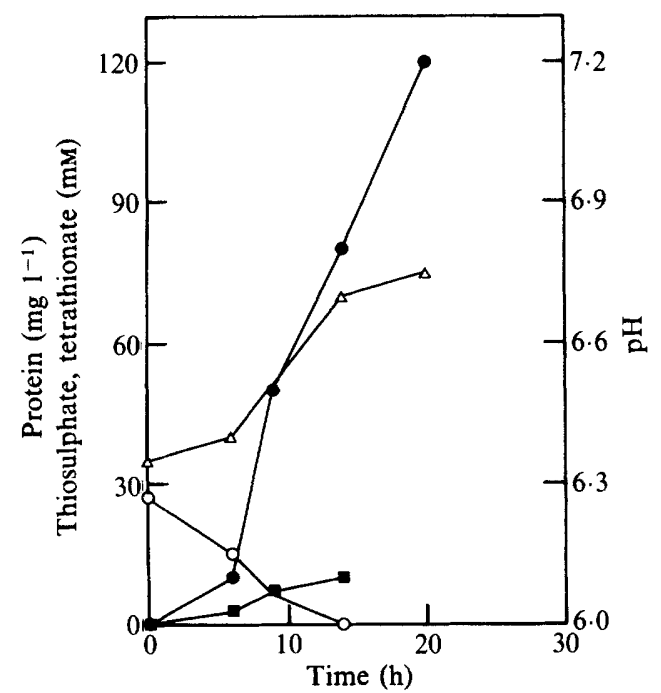

Fig. 2. Growth and thiosulphate oxidation in batch cultures of strain TG 5-3 supplied with acetate $(10 \mathrm{~mm}) .0$, Protein; $\bigcirc$, thiosulphate; tetrathionate; $\triangle, \mathrm{pH}$. yield increase was proportional to the amount of thiosulphate added (data not shown). However, when other organic substrates (succinate, fumarate, lactate, pyruvate, glucose, glutamate) were used, this increase was not observed, even though the thiosulphate was oxidized. The reasons for this are not clear, but may be linked to $\mathrm{pH}$ since the stimulatory effect of thiosulphate was more evident in acetate-grown cultures with a low initial pH (Fig. $3 a$ ) than a higher one (Fig. 3c).

Cell extracts of strain TG 5-3 oxidized thiosulphate very slowly, with a maximum rate of $25 \mathrm{nmol} \mathrm{min}^{-1}(\mathrm{mg}$ protein $)^{-1}$. The activity was not stimulated by the addition of oxidized mammalian cytochrome $c_{550}$, a finding which supports the observed low activity of thiosulphate-cytochrome $c_{550}$ oxidoreductase: about

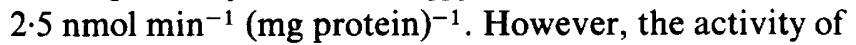
thiosulphate-ferricyanide oxidoreductase, at $950 \mathrm{nmol}$ $\min ^{-1}(\mathrm{mg} \text { protein })^{-1}$, was much higher. Thiosulphate

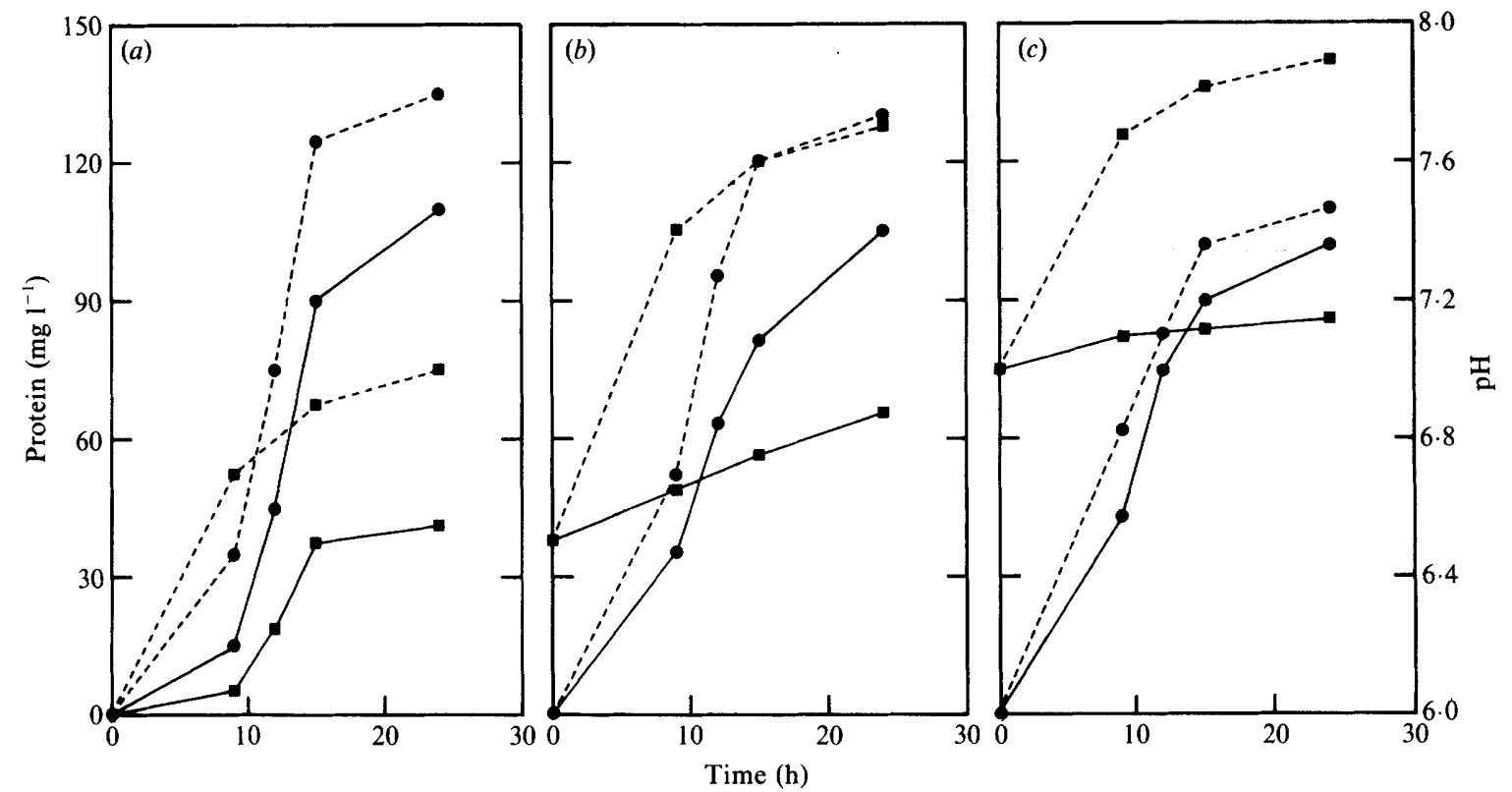

Fig. 3 Influence of $20 \mathrm{~mm}$-thiosulphate on growth in batch cultures (10 mM-acetate) of strain TG 5-3. (a) Initial pH 6.0; (b) initial pH $6.5 ;(c)$ initial pH 7.0. Growth with $(-\cdots)$ and without $\left(-\infty \begin{array}{l}- \\ -\end{array}\right)$ thiosulphate.

Table 1. Comparison of strain TG 5-3 with the genus Neisseria

\begin{tabular}{lcc}
\hline \hline Property & TG 5-3 & Neisseria \\
\hline Morphology & $\begin{array}{c}\text { Chains of cocci, transient } \\
\text { formation of rods } \\
\text { One plane }\end{array}$ & $\begin{array}{c}\text { Mostly diplococci, sometimes cocci in short chains; } \\
\text { one species rod-shaped } \\
\text { Two planes }\end{array}$ \\
Division & + & \pm \\
Acid production from sugars & + & - \\
Anaerobic growth with sugars & - & $46 \cdot 5-53 \cdot 5^{*}$ \\
Anaerobic growth with nitrite & $49 \cdot 8$ & $49 \cdot 5-55 \cdot 6 \dagger$ \\
Mol\% of G+C & Sulphidic seawater & Mammalian materials \\
Habitat & Vedian
\end{tabular}

* Vedros (1984). † Morse \& Knapp (1992). 
immediately reduced cytochrome $c_{553}$ when added to cell extracts (to about $70 \%$ of the reduction reached with dithionite). This result may indicate that the thiosulphate-cytochrome $c$ oxidoreductase in these cells is specific to its own cytochrome $c$, as has previously been reported for enzymes from marine pseudomonads (Tuttle et al., 1983) and Rhodotorula sp. (Kurec, 1985).

Strain TG 5-3 did not reduce sulphate or tetrathionate under anaerobic conditions with acetate or glucose as electron donors. Although it could oxidize sulphur aerobically (results not shown), it was also able to reduce $\mathrm{S}^{0}$ to $\mathrm{H}_{2} \mathrm{~S}$ under microaerobic conditions (dissolved oxygen was $1-5 \%$ of air saturation) with acetate or glucose as electron donors, and during anaerobic incubation with glucose.

\section{Discussion}

The new isolate, strain TG 5-3, cannot be easily placed in any known genus of Gram-negative bacteria. It differs from Thiosphaera and Paracoccus by its low mol $\% \mathrm{G}+\mathrm{C}$ and inability to grow chemolithoautotrophically, from Neisseria by its ability to ferment and thus grow anaerobically on sugars, and from the fermentative bacteria by its morphology. Among the Gram-negative cocci, strain TG 5-3 most closely resembles the genus Neisseria (e.g. mol \% G $+\mathrm{C}$ and morphology). However, strain TG 5-3 differs in a number of significant aspects from Neisseria, including the ability to ferment sugars, an inability to grow anaerobically with nitrite as an electron acceptor, an ability to oxidize reduced sulphur compounds (thiosulphate, sulphur) and reduce sulphur, and growth in a marine habitat (Table 1). A computer analysis of the results of the various API 20 tests showed strain TG 5-3 to be different from any known bacterial species. Formation of a new genus is therefore proposed to accommodate this strain. Because of its fermentative nature, and because thiosulphate oxidation terminates at tetrathionate, rather than sulphate (as it does in the respiratory colourless sulphur bacteria included in the genera Thiobacillus, Thiomicrospira and Thiosphaera), it does not seem appropriate to assign the prefix Thio- to its genus. Strain TG 5-3 has therefore been assigned the name Catenococcus thiocyclus in recognition of its ability to oxidize as well as reduce sulphur compounds and its tendency to grow as chains of cocci. A culture has been deposited in the Netherlands Culture Collection (Delft) under this name, and has been designated the type species of the genus. It has the collection number LMD 92.12.

\section{Description of the genus Catenococcus}

Caten.o.cocc'us. L. n. catena, chain; Gr. n. coccus, berry. Catenococcus, a chain of berries.

Non-motile, Gram-negative coccoid cells, occurring singly, in pairs and chains, surrounded by slime. Facultatively anaerobic and able to ferment sugars. Acid is produced during aerobic growth on sugars. Can oxidize thiosulphate to tetrathionate when growing chemolithoheterotrophically on acetate and thiosulphate. Does not grow chemolithoautotrophically on thiosulphate. Can reduce hydrophobic molecular sulphur to sulphide in the presence of organic electron donors under microaerobic and anaerobic conditions. The respiratory chain includes cytochromes $b$ and $c$. Oxidase and catalase positive. $\mathrm{pH}$ range for growth 5.6-7.8 (optimum 6.7-6.9), temperature range $10-35^{\circ} \mathrm{C}$ (optimum $\left.25-28{ }^{\circ} \mathrm{C}\right) . \mathrm{Mol} \% \mathrm{G}+\mathrm{C}$ in DNA $49.8 \pm 0.5\left(T_{\mathrm{m}}\right)$. Isolated from sulphidic marine water.

Type species Catenococcus thiocyclus LMD 92.12 (Netherlands Culture Collection, Delft). thi.o.cy'clus. Gr. n. thios, sulphur; Gr. n. cyclos, a circle. thiocyclus, a sulphur circle. Description as in the above paper.

The author would like to thank Jannie Gruwel for help with the API tests, Marten Hazelaar for the cytochrome spectra and Dr Lesley A. Robertson for constructive criticism of the manuscript.

\section{References}

CyPionKa, H. \& Pfennig, N. (1986). Growth yield of Desulfotomaculum orientis with hydrogen in chemostat culture. Archives of Microbiology 145, 396-399.

DAWES, C. J. (1971). Biological Techniques in Electron Microscopy. New York: Barnes \& Noble.

Goehring, M., Feldman, U. \& Hebing, H. (1949). Quantitative Bestimmung der Polythionates. Zeitschrift für Analytische Chemie 129, 346-354.

JøRGENSEN, B. B. (1989). Biogeochemistry of chemolithotrophic bacteria. In Autotrophic Bacteria, pp. 117-146. Edited by H. G. Schlegel. Madison, Wisconsin: Springer.

Kelly, D. P. \& Harrison, A. P.(1989). Genus Thiobacillus. In Bergey's Manual of Systematic Bacteriology, vol 3, pp. 1842-1858. Edited by J. T. Staley, M. P. Bryant, N. Pfennig \& J. G. Holt. Baltimore: Williams \& Wilkins.

KUENEN, J. G. (1989). Colourless sulphur bacteria. In Bergey's Manual of Systematic Bacteriology, vol 3, pp. 1834-1837. Edited by J. T. Staley, M. P. Bryant, N. Pfennig \& J. G. Holt. Baltimore: Williams \& Wilkins.

Kuenen, J. G., Robertson, L. A. \& Tuovinen, O. H. (1992). The genera Thiobacillus, Thiomicrospira and Thiosphaera. In The Prokaryotes, vol. 3, pp. 2638-2657. Edited by A. Balows, H. G. Trüper, M. Dworkin, W. Harder \& K. H. Schleifer. New York, Berlin \& Heidelberg: Springer.

KUREK E. (1985). Properties of enzymatic complex active in sulphite and thiosulphate oxidation by Rhodotorula sp. Archives of Microbiology 143, 277-282.

MARMUR, J. (1961). A procedure for isolation of DNA from microorganisms. Journal of Molecular Biology 3, 208-214.

MASON, J. \& KELLY, D. P. (1988). Thiosulphate oxidation by obligately heterotrophic bacteria. Microbial Ecology 15, 123-134. 
2292

D. Mu. Sorokin

Morse, S. A. \& KnApp, J. S. (1992). Genus Neisseria. In The Prokaryotes, vol 3, pp. 2496-2592. Edited by A. Blows, H. G. Trüper, M. Dworkin, W. Harder \& K. H. Schleifer. New York, Berlin \& Heidelberg: Springer.

PFENNIG, N. \& LIPPERT, R. D. (1966). Uber dos Vitamin B B $_{12}$-Bedürfnis phototropher Schwefelbakterien. Archives of Microbiology 55, 245256.

Robertson, L. A. \& Kuenen, J. G. (1992). The colourless sulfur bacteria. In The Prokaryotes, vol 1, pp. 386-413. Edited by A. Balows, H. G. Trüper, M. Dworkin, W. Harder \& K. H. Schleifer. New York, Berlin \& Heidelberg: Springer.

Robertson, L. A., Cornelisse, R., Zing, R. \& Kuenen, J. G. (1989). Effect of thiosulphate and other inhibitors of autotrophic nitrificaion on heterotrophic nitrifies. Antone van Leeuwenhoek 56, 301309.

SöRBO, B. (1957). A colorimetric determination of thiosulphate. Biochimica et Biophysical Alta 23, 412-416.

SOROKIN, D.YU. (1991 a). Oxidation of reduced sulphur compounds by heterotrophic microorganisms. Izvestia Academii Nark (Ser. Biol) 20 , $558-570$ (in Russian).

SoROKIN, D.YU. (1991 b). Oxidation of reduced sulphur compounds in volcanically active regions of Plenty Bay (New Zealand) and Matupy Harbour (New Britain Island, Papua-New Guinea). Izvestia Rcademii Sauk (Ser. Biol) 20, 376-387 (in Russian).

SorokIN, D.YU. (1992). Thiosulphate oxidation by heterotrophic bacteria from aquatic habitats. Mikrobiologia 61 (in the Press) (in Russian).

TutTle, J. H. \& Jannasch, H. W. (1972). Occurrence and types of Thiobacillus-like bacteria in the sea. Limnology and Oceanography 17, $532-543$.

Turtle, H. J., Schwartz, J. H. \& Whited, G. M. (1983). Some properties of thiosulphate oxidizing enzyme from marine heterotroph 16B. Applied and Environmental Microbiology 46, 438-445.

Vedros, N. A. (1984). Genus Neisseria. In Bergey's Manual of Systematic Bacteriology, vol 1, pp. 290-296. Edited by N. R. Grieg \& J. G. Holt. Baltimore: Williams \& Wilkins. 